\title{
粘性土盛土中の高強度ジオウオーブン補強材 （織布）の現場引抜き試験
}

\author{
角田起 1 吉田浩一 2 ・佐藤和之 ${ }^{3}$
}

\begin{abstract}
本現場は現場発生土（高含水比粘性土）を用いた高盛土が計画されており（勾配1:1.8、最大盛土高24m）， その中で工法の施工性・経済性などが総合的に検討され、盛土補強材として高強度ジオウォーブンを使用する ことが決定された。

現在、ジオテキスタイルを用いた盛土の補強は実績も多く、広く普及してきているが使用されるジオテキス タイルはインターロッキング効果が期待されるグリッド状の製品が多い。ジオウオーブンについてはジオグリ ッドに比ベ、インターロッキング効果が期待できず引抜き抵抗力は低下すると考えられる。ここで紹介する事 例は実施工に先立って、原位置で実施したジオウォーブンの土中引抜き試験に関する報告である。
\end{abstract}

キーワード : ジオウォーブン，引抜き試験, 粘性土

1.はじめに

盛土補強において、土中に敷設されたジオテキスタイ ルは、盛土材との間で十分な摩擦力を発揮して、引張力 を負担しなければならない。よって、盛土を設計、構築 する場合、盛土材とジオテキスタイルの摩擦特性を把握 する事が重要になる。摩擦特性を把握するためには、引 抜き試験または、一面せん断試験を行う必要があるが、 その試験は室内で行われており、現地での締固め状況と は異なる環境で行なわれている。今回の試験は、実際の 現地発生土を使用した試験盛土において、盛土補強のジ オウォーブンが設計值以上の引抜き抵抗力を満足してい るかどうかを確認するため引抜き試験を実施した。

\section{2. 試験盛土の概要と使用材料}

\section{（1）試験盛土概要と盛土材料}

現場発生土は三軸圧縮試験（UU）を行った結果、大 きく分けて 2 種類存在し、

(1)『細粒分まじり砂質碩（シルト・粘土分7.3\%)』

(2)『細粒分質砂質碟（シルト・粘土分 $34.3 \%$ )』である。 現場状況から判断すると(1)のよう䃇分が多い材料も見 られるが、基本的には(2)の粘性土が中心となっている (表-1)。

また、盛土形状は、現場の締固め層圧 : $30 \mathrm{~cm}$ 考慮 して、上載盛土高さ $\mathrm{H}=0.6 \mathrm{~m} 、 0.9 \mathrm{~m} 、 1.2 \mathrm{~m}$ の 3 ケースとし た（図-1）。
表-1 盛土材料(2)試験結果

\begin{tabular}{|c|c|c|}
\hline \multicolumn{1}{|c|}{ 項目 } & 試験値 & 備考 \\
\hline $\begin{array}{c}\text { 単位体積重量 } \\
\gamma\left(\mathrm{kN} / \mathrm{m}^{3}\right)\end{array}$ & 19.54 & $\begin{array}{l}\text { 砂置換法による } \\
\text { 密度試験より }\end{array}$ \\
\hline 粘着力 $\mathrm{c}\left(\mathrm{kN} / \mathrm{m}^{2}\right)$ & 31.66 & UU試験より \\
\hline 内部摩擦角 $\phi\left({ }^{\circ}\right)$ & 4.07 & " \\
\hline
\end{tabular}
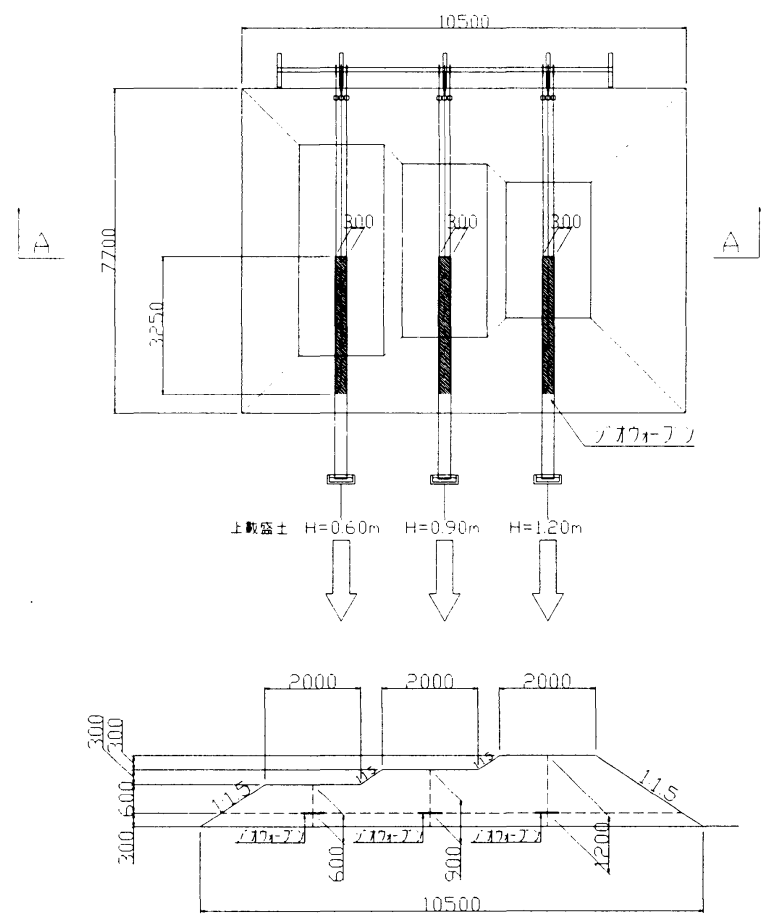

図-1 試験盛土概要図

1正会員, 前田工繊株式会社 営業推進部（テ103-0005 東京都中央区日本橋久松町9-9 AIG日本橋ビル5F）

2正会員, 前田工繊株式会社 営業本部 （广910-0422福井県坂井郡春江町沖布目38-3）

3正会員, 前田工㵶株式会社 営業本部 札幌営業所（T060-0809札幌市北区北九条西3-19-1 ノルテプラザ6F） 


\section{（2）ジオウォーブン材料}

本現場で使用されるジオテキスタイルは特殊ポリエ ステル繊維製の高強度ジオウォーブンで、織り方に特徴 があり伸度を低くするための工夫がなされている。単位 断面積あたりの縌系の本数が多い特殊な織構造で、それ が対強度比重量を軽くし、しかも構造的伸びを抑える働 きをしている。また、排水を目的とした材料ではないが、 通水性が良いために、盛士内に敷設した場合、これが不 透水層となることがない。製品は引張強度150〜 $1000 \mathrm{kN} / \mathrm{m}$ のものまであり、本現場で使用されるものは $150 \mathrm{kN} / \mathrm{m}$ と200kN/mの2タイプで、引抜き試験で採用した 製品は最大引張強度 $150 \mathrm{kN} / \mathrm{m}$ のタイプである。

表-2 使用ジオウォーブン諸元

\begin{tabular}{|l|c|c|c|c|c|}
\hline 試料 & \multicolumn{5}{|c|}{$150 \mathrm{kN} / \mathrm{m}$ タイプ } \\
\hline 素材 & \multicolumn{5}{|c|}{135} \\
\hline $\begin{array}{c}\text { 製品基準強度 } \\
(\mathrm{kN} / \mathrm{m})\end{array}$ & \multicolumn{5}{|c|}{365} \\
\hline $\begin{array}{c}\text { 単位面積質量 } \\
\left(\mathrm{g} / \mathrm{m}^{2}\right)\end{array}$ & \multicolumn{5}{|c|}{} \\
\hline $\begin{array}{c}\text { クリープ } \\
\text { 低減倸数 }\end{array}$ & 1 年 & 2年 & 5 年 & 60 年 & 120 年 \\
\cline { 2 - 7 } & 0.72 & 0.71 & 0.70 & 0.67 & 0.66 \\
\hline
\end{tabular}

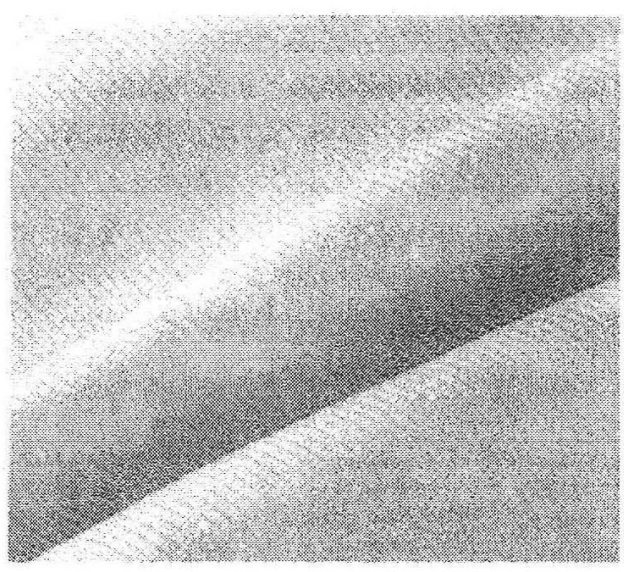

図-2 ジオウォーブン外観

\section{3. 試験方法}

ジオウォーブンの材料巾を $0.30 \mathrm{~m}$ 、土中内の長さを $3.25 \mathrm{~m}$ として試験を行った。試験盛土前方に重機を設置 し、それを反力としセンターホールジャッキで引抜く。 引張力についてはロードセルで荷重を測定する。

土中内のジオウォーブンの変位を測定するため、ジ オウォーブンに変位伝達ロッドを取付け、変位計にて測 定を行った。また、上載荷重を測定する為、土圧計を盛 土内に設置した。各計測器及び治具を図-3〜図-6に示寸。

ジオウォーブン敷設基盤、および敷設後の上載盛土 については現場の締固め管理基淮と同様にし、層厚管理 は0.3mで85\%以上の締固め度を確保した。

現場試験状況を図-7〜図-9に示す。
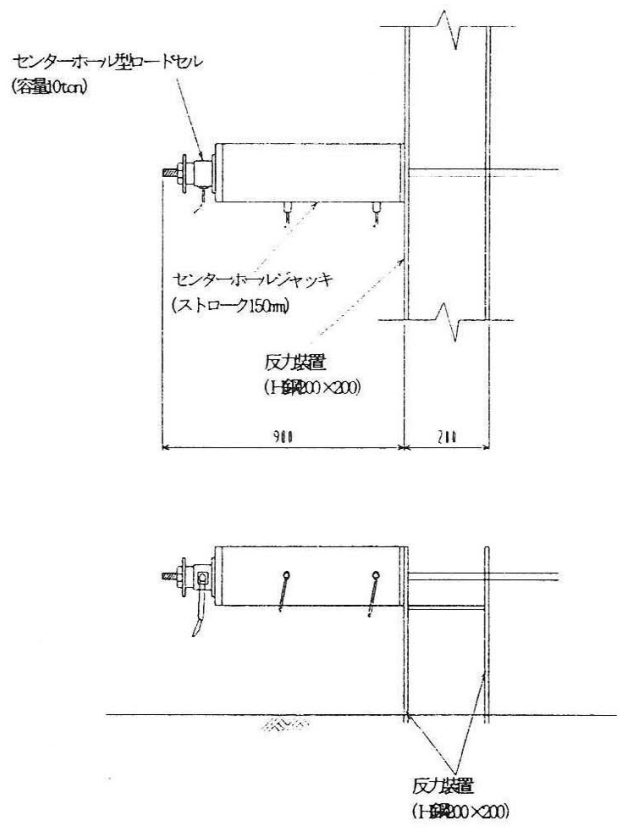

図-3 引抜き試験装置

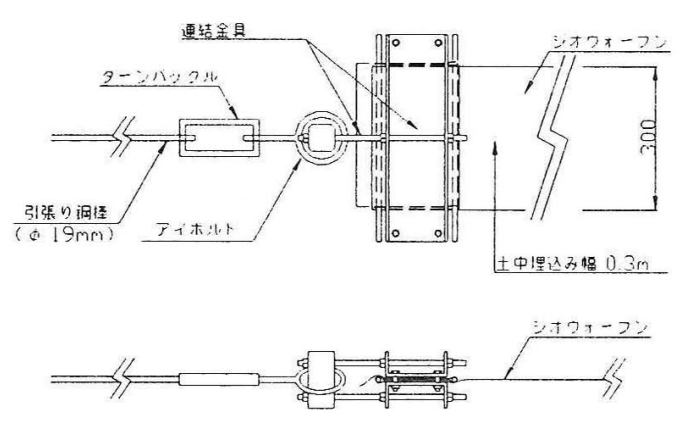

図-4 ジオウォーブン連結冶具
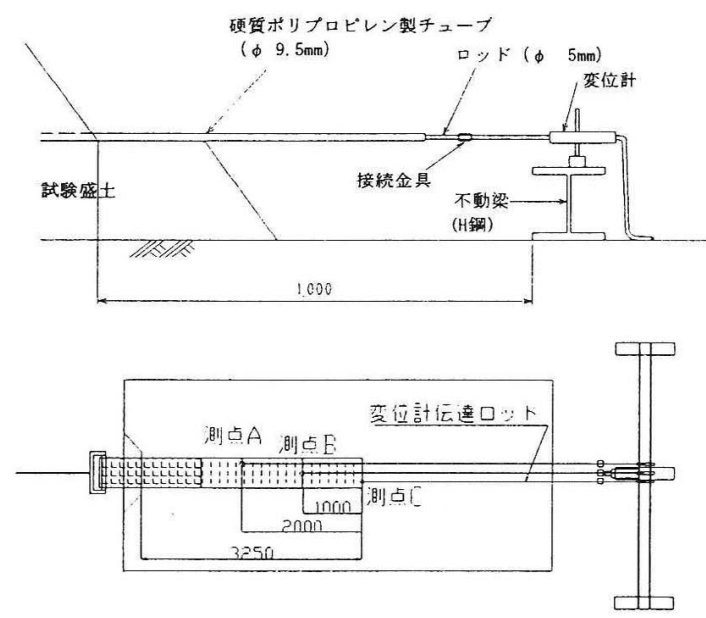

図-5 変位計取付図 


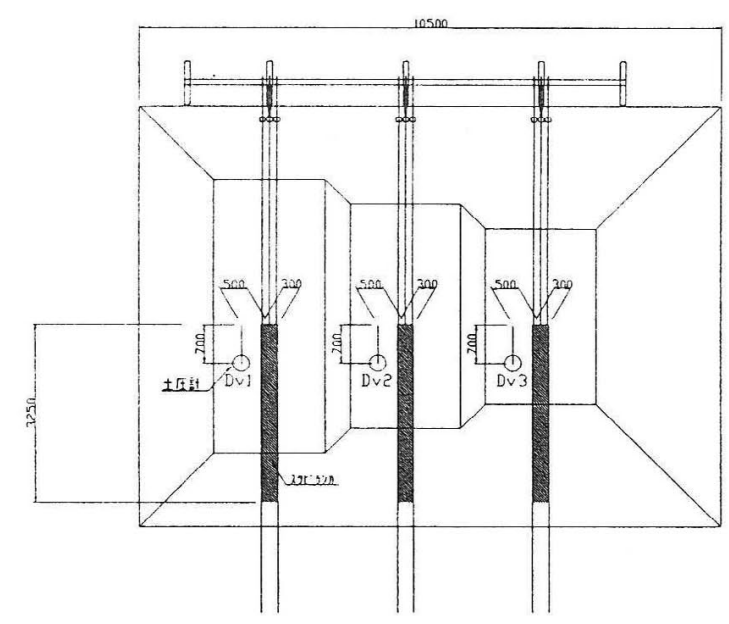

図-6 土圧計設置位置

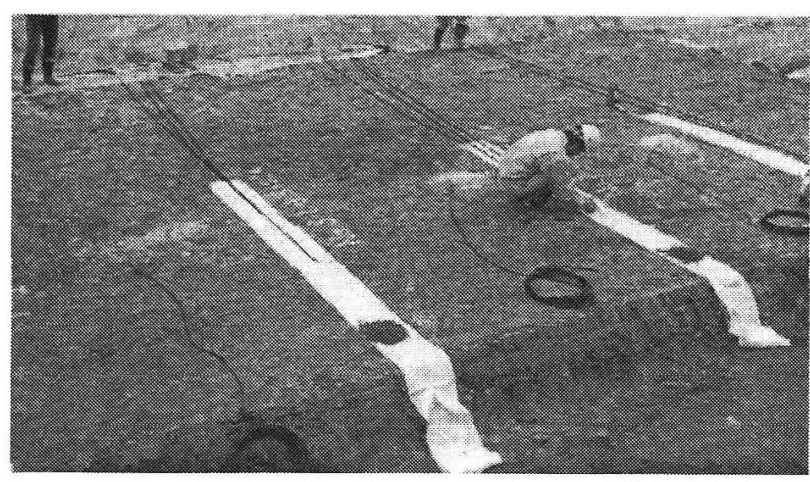

図-7 ジオウォーブン敷設状況

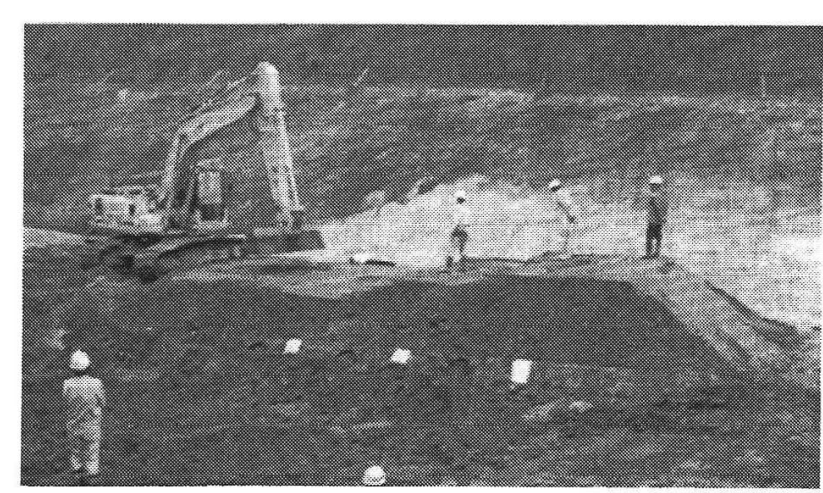

図-8 上載盛土構築状況

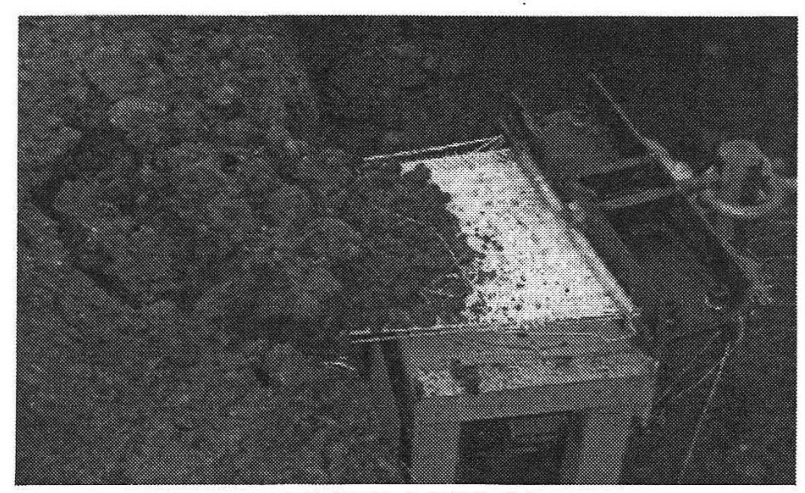

図-9 引抜き試験状況

\section{4. 試験結果と考察}

\section{（1）上載荷重について}

盛土内に設置した土圧計の測定值 $\sigma$ と、盛土材の単 位体積重量 $\left(\gamma=19.54 \mathrm{k} / \mathrm{m}^{3}\right)$ を用い以下の式(1) 力兄算出 した荷重 $\sigma$ 'の関倸を比較した。

土圧計による荷重はバラツキが大きく、正確な土圧 は計測されなかった。原因としては粒径の大きな碩材が 接触した、均一な転圧ができていなかった、土圧計の位 置（各高さごとの盛十の距離が近い）などの要素が考え られる。しかし、引抜きが始まり荷重がかかっていくに つれ、ジオウォーブン周辺の盛土材料に影響を与え、土 圧が抜けていく（減少する）傾向は測定できた（図一 10)。

$$
\sigma^{\prime}=\gamma \times \mathrm{h}
$$

表-3 盛土厚から算出した荷重と土圧計による荷重

\begin{tabular}{|c|c|c|}
\hline $\begin{array}{c}\text { 上載盛土高 } \\
\text { さ } \\
\text { (m) }\end{array}$ & $\begin{array}{c}\text { 盛土厚から算出 } \\
\text { した上載荷重 } \\
\sigma^{\prime} \quad\left(\mathrm{kN} / \mathrm{m}^{2}\right)\end{array}$ & $\begin{array}{c}\text { 土压計による荷重 } \\
\sigma \quad\left(\mathrm{kN} / \mathrm{m}^{2}\right)\end{array}$ \\
\hline $0.60\left(D_{v_{1}}\right)$ & 11.73 & 15.30 \\
\hline $0.90\left(\mathrm{Dv}_{2}\right)$ & 17.59 & 11.70 \\
\hline $1.20\left(\mathrm{Dv}_{3}\right)$ & 23.45 & 31.50 \\
\hline
\end{tabular}

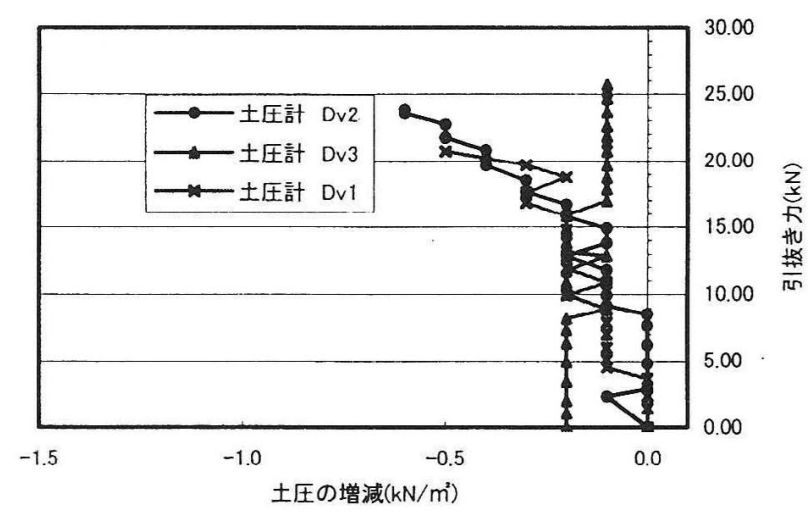

図-10 土圧の增減

(2) 変位について

図-11 に、各盛土高さにおける引抜き力と変位計変位 量関係を示した。ジオウォーブンの変位は $\mathrm{H}=1.2 \mathrm{~m}$ 、 $H=0.6 \mathrm{~m}$ では引抜き側の測点 $\mathrm{A}$ でのみ変位がみられた。 $\mathrm{H}=0.9 \mathrm{~m}$ では測点 $\mathrm{B}$ にも変位量が測定された。この $\mathrm{H}=$ 0.9m の試験ではジャッキストローク $(150 \mathrm{~mm})$ が一度限 界まで達し、再度ジャッキを設置し直し、試験を継続し たため合計のジャッキストロークが大きくなり、測点 $\mathrm{B}$ の位置まで変位が出たものと考えられる。

変位量は盛十高が高い方が大きな変位が出るなどバラ ツキが大きかった。これは、ジオウォーブン敷設時に各 試験体に均等な緊張をかけられなかったこと、連結部か ら盛土までの距離にバラツキがあり、材料自体の伸びが 
影響していることなどの原因が考えられる。

測点Cの変位量が各盛土高とも0であったのは、ジオウ オーブンの破断やジャッキストロークの関係で土中埋込 み長さ3.25mが引抜けていく段階までは試験は行えなか ったためで、傾向としては引抜き側から順に変位が出て いる事がわかる。

\section{(3) 引抜きカについて}

各盛土高さでの最大引抜き力と設計計算上の引抜き力 を表-4 に示す。前項で述べたように、各盛土高さとも 引抜き挙動が起きる前の段階で試験終了しているが、す べての盛土高さで設計計算上の引抜き力を上回る結果は 確認された。

設計計算上の引抜き力算出には「ジオテキスタイル の設計・施工マニュアル」に記載されている以下の (2) 式を用いた。本現場では大別して 2 種類の盛土材料が存 在していると述べたが、実施工現場では細粒分の多い粘 性土で盛土が構築されていく可能性が高く、表-1の盛土 条件で設計引抜き力を算出した。

$$
T=\frac{2\left(\alpha_{1} \cdot c+\alpha_{2} \cdot \sigma_{v} \cdot \tan \phi\right)}{F_{s}} \times A
$$

表-4 最大引抜き力と設計引抜き力

\begin{tabular}{|c|c|c|c|}
\hline $\begin{array}{c}\text { 盛土高さ } \\
\mathrm{H}(\mathrm{m})\end{array}$ & $\begin{array}{c}\text { 最大引抜力 } \\
\mathrm{P}(\mathrm{kN})\end{array}$ & $\begin{array}{c}\text { 設計計算上の } \\
\text { 引抜き力 }(\mathrm{kN})\end{array}$ & 判定 \\
\hline 1.20 & $25.67 ※ 1$ & 16.61 & $\mathrm{OK}$ \\
\hline 0.90 & $23.78 ※ 2$ & 16.40 & $\mathrm{OK}$ \\
\hline 0.60 & $20.71 ※ 3$ & 16.04 & $\mathrm{OK}$ \\
\hline
\end{tabular}

備考） ※1 ジャッキストローク限界で終了

※2 ジャッキストローク限界により試験一旦停止 裁設置後再開で破断前で終了。

※3 ジャッキストローク限界で終了

各盛土高さの試験ともジャッキストローク限界、破 断直前または破断で試験を終了した。使用したジオウオ ーブンの最大強度は $150 \mathrm{kN} / \mathrm{m}$ であり、本試験体幅 $0.3 \mathrm{~m}$ であれば単純に $150 \mathrm{kN} / \mathrm{m} \times 0.3 \mathrm{~m}$ で $45 \mathrm{kN}$ の破断強度が期待 できる。しかし、実際には $45 \mathrm{kN}$ 以下の引抜き力で破断 が起きているものもある。この原因としては、荷重がジ オウォーブンの幅方向に均等に作用せずジオウォーブン に局所的に応力が集中した事、試験体作成時に幅方向の 端部処理が不十分でほつれが出たこと、などが考えられ る。（実施工現場の補強盛土においては、使用するジオ ウォーブンは $5 \mathrm{~m}$ の広幅であり端部処理されている)

また、ジオウォーブンの破断とジャッキストローク の関係で設計值以上引抜き力が測定された時点で、試験
を終了したため、引抜け挙動までは把握できなかったが、 実際の引抜き抵抗力はもつと高いものと考えられる。
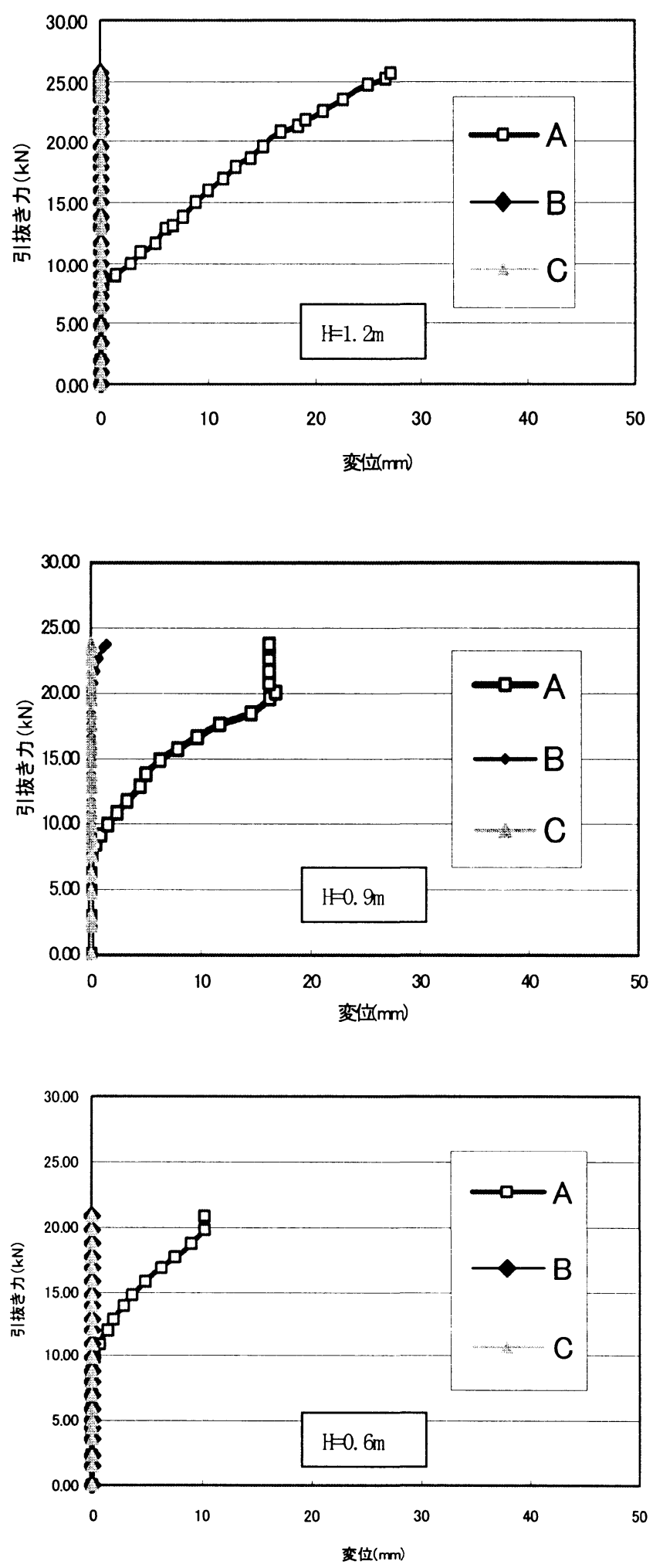

図-11 引抜き力と変位量の関係 
（4）見かけのせん断抵抗角について

ジオウォーブンの摩擦抵抗は、以下の式で盛土高さ 毎の最大引抜き力を面積で除して、最大せん断応力を算 出した。表-5に盛土高さと最大せん断応力を示す。

$$
\tau=\frac{P}{2 A}
$$

表-5 盛土高さと最大せん断応力

\begin{tabular}{|c|c|c|}
\hline $\begin{array}{c}\text { 盛土高さ } \\
\mathrm{H}(\mathrm{m})\end{array}$ & $\begin{array}{c}\text { 最大引抜力 } \\
\mathrm{P}(\mathrm{kN})\end{array}$ & $\begin{array}{c}\text { 最大せん断応力 } \\
\tau\left(\mathrm{kN} / \mathrm{m}^{2}\right)\end{array}$ \\
\hline 1.20 & 25.67 & 13.16 \\
\hline 0.90 & 23.78 & 12.19 \\
\hline 0.60 & 20.71 & 10.62 \\
\hline
\end{tabular}

最大せん断応力 $\tau$ とジオウオーブンに作用する鉛直 応力 $\sigma$ の関係 $(\tan \phi=\tau / \sigma)$ から、ジオウォーブンと 盛土材の見かけのせん断抵抗角 $\phi_{\mathrm{p}}$ を求めた。ここでは、 ジオウォーブンに作用する鉛直応力は、盛土厚から算出 した荷重 $\sigma^{\prime}$ を採用した。この結果から、見かけのせん 断抵抗角 $\phi_{\mathrm{p}}=11^{\circ}$ が確認できた。最大せん断応力とジオ ウォーブンに作用する鉛直応力の関係を図-12 に示す。

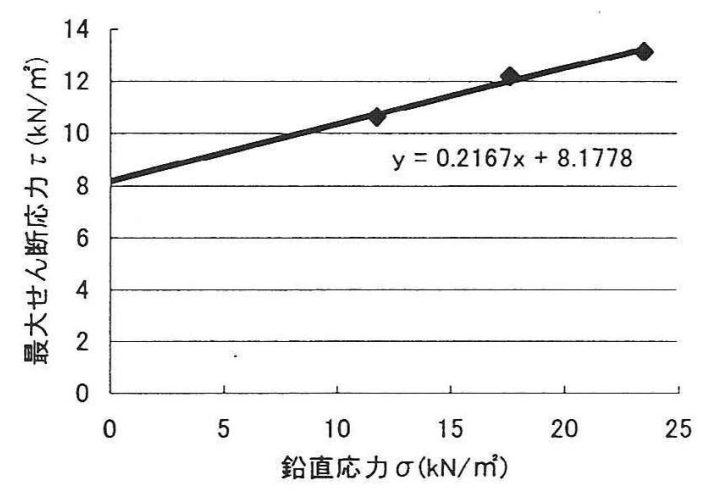

図-12 最大せん断応力と鉛直応力の関係

本試験では設計上の引抜き力と試験測定値を比較し、 測定値の方が上回る数值を確認することが目的であった。 そのため、試験は引抜き挙動が発生する前に試験終了し ている。また設計値との比較ということで、T は安全率 で除したものとしている。

ジオテキスタイルの引抜き抵抗性は盛土材料によっ て異なる。ジオグリッドの場合の引抜き抵抗性は、目合 いの大きさと土粒子の粒径の違いにより異なる。本試験 および本現場では盛土材料が粘性土であることから、ジ オグリッドあるいはジオウォーブンの引抜き抵抗性は、
粘性土のせん断特性に依存するため、両者に大きな差異 は見られないと考えられる。

また、高含水比粘性土の盛土補強においては、排水 補強材として不織布が使用されている。これは透水性と 透水断面を確保しやすいことから適用されている。しか し、盛土高さが高くなると鉛直応力が増加し圧縮され、 透水係数および透水断面が減少する。しかし、本現場で 使用するジオウォーブンの場合、透水断面が減少しにく い。引張強度特性も異方性を有しており、強度方向（た て）の繊維密度が高く、たて方向の通水性が高くなる傾 向を示すことから厚密促進効果を発揮するものと考えら れ、高含水比粘性土の盛土補強に対して排水補強効果も 期待できる。

以上の試験結果と見解から本現場では盛土補強材と してジオウォーブンを用いて施工を行うこととなった。 図一13、14に本現場の標準断面図と施工状況を示寸。

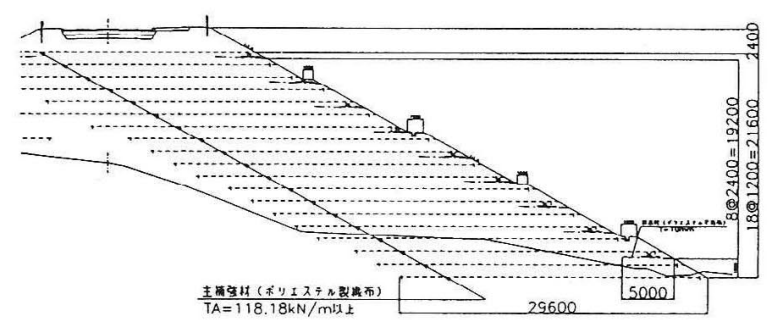

図-13 標淮断面図

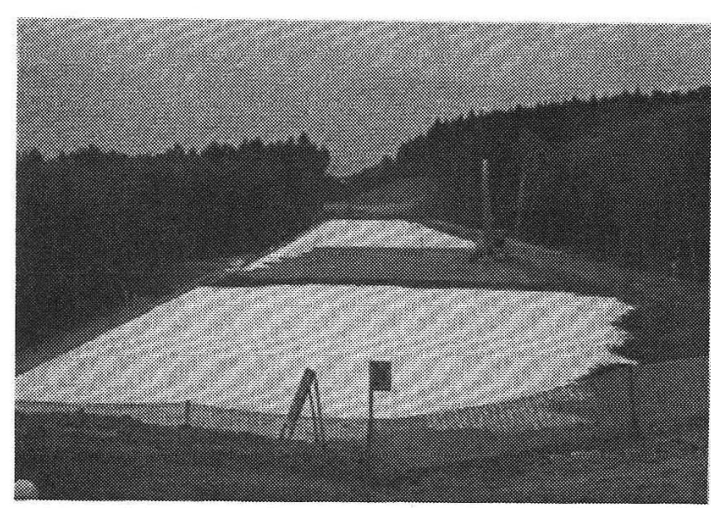

図-14 本施工状況

5.まとめ

試験結果加ら知見を以下に示す。

(1) 盛土内に設置した土压計の結果。はバラツキが大 きく、盛土材の現場密度試験の結果を用いて算出 した荷重 $\sigma$ と比較することはできなかった。

(2) 变位については引抜け挙動まで確認できなかった が、引抜き側から順に変位が出ていることが確認 できた。

(3) 最大引抜き力について、設計計算上で求めた引抜 き力と試験結果を比較すると、すべての盛土高さ で試験結果が上回った。 
(4) 最大せん断応力 $\tau$ とジオウオーブンに作用する鉛 直応力 $\sigma$ の関係からジオウォーブンと盛土材の見 かけのせん断抵抗角 $\phi_{\mathrm{p}}=11^{\circ}$ が確認できた。

今回の試験結果から、本現場で使用するジオウォーブ ンは現地発生土との間で十分な摩擦力を発揮し、引張 力を負担できることが確認された。

今後、さらに多くの現場で計測、そして室内試験を行 い、性能・施工性・経済性に魅力ある引張補強材とし ての高強度ジオウォーブンの信頼性を高めていきたい。

謝辞 : 本計測において多くの方々に多大なる協力を頂い た。末尾ではありますが、ここに特記し関係者各位に謝 意を表します。

\section{参考文献}

1) 伊藤修二・横田善弘・福原慶一・前田修 : ジオグリッドの 現場引抜き試験、ジオシンセティックス論文集第14巻 1999

2) ジオテキスタイル補強土工法普及委員会 : ジオテキスタイ ルを用いた補強土の設計・施工マニュアル改訂版、土木研 究センター 2000

3) 井澤淳・木村博憲・桑野二郎・高橋章浩・石濱吉郎 : ジオ グリッド形状が引抜き特性に及ぼす影響、ジオシンセティ ックス論文集第 15 巻 2000 .

4) 石濱吉郎・桑野二郎・高橋章浩・井澤淳 : ジオグリッドの 伸び特性が引抜き抵抗に及ぼす影響、ジオシンセティック 論文集第16巻 2001

5）林雄介・井澤淳・石濱吉郎・桑野二郎・高橋章浩 : ジオグ リッドの引抜き特性に及ぼす粒子経の影響、ジオシンセテ イックス論文集第17巻 2002

\title{
PULLOUT TESTS OF GEOWOVEN IN HIGH WATER CONTENT CLAY
}

\author{
Hajime TSUNODA, Koichi YOSHIDA and Kazuyuki SATO
}

\begin{abstract}
This construction place is planning the high embankment that used high water content clay (All height $24 \mathrm{~m}$ ). The construction nature, the economical efficiency, etc. of a method of construction were synthetically examined in it. And having used high-strength geowoven as embankment reinforcement material was determined. Now, reinforcement of the embankment using the geotexile has many actual results. But the geotexile used has many grid products with which the restricted effect is expected. The example introduced here is related with the pull out test in the embankment of geowoven carried out in the original position in advance of construction.
\end{abstract}

